\title{
Party families and greenhouse gas emissions: a new perspective on an old concept
}

\section{Detlef Jahn}

Published online: 21 December 2021

(C) The Author(s) 2021

\begin{abstract}
Partisan theory is not easy to apply to environmental issues. One reason for this is that party families are usually structured according to the left-right dimension. However, such a perspective ignores the fact that the concept of party families stems from a multi-dimensional historical analysis. In order to determine the relevance of the influence of party families on greenhouse gas emissions (GHGEs), we use a new data set that differentiates between ten party families. An organization theoretical analysis shows that the participation of green parties in government reduces GHGEs. Left parties have much less impact. In contrast, non-Christian center parties have a negative effect on GHGEs. Methodologically, we show that the party effect does not appear in the short term, but only takes effect after more than two years
\end{abstract}

Keywords Climate change $\cdot$ Left and right ideology $\cdot$ Partisan theory $\cdot$ Party families · Optimized lags 


\section{Parteienfamilien und Treibhausgasemissionen: Eine neue Perspektive auf ein altes Konzept}

Zusammenfassung Die Parteiendifferenzhypothese lässt sich nicht leicht auf Umweltfragen anwenden. Ein Grund dafür ist, dass Parteifamilien üblicherweise nach der links-rechts-Dimension strukturiert sind. Eine solche Perspektive ignoriert jedoch, dass das Konzept der Parteifamilien aus einer mehrdimensionalen historischen Analyse stammt. Um die Relevanz des Einflusses von Parteienfamilien für die Treibhausgasemissionen zu erfassen, benutzen wir einen neuen Datensatz der zehn Parteienfamilien unterscheidet. Eine organisationstheoretische Analyse zeigt, dass eine Regierungsbeteiligung grüner Parteien die Treibhausgasemissionen reduzieren. Linke Parteien haben eine viel geringere Wirkung. Dagegen haben nichtchristliche Zentrumsparteien eine negative Wirkung auf Treibhausgasemissionen. Methodologisch zeigen wir, dass sich der Parteieneffekt nicht kurzfristig einstellt, sondern erst nach mehr als zwei Jahren wirksam wird.

Schlüsselwörter Klimawandel · Links und rechts Ideologie · Parteiendifferenztheorie $\cdot$ Parteifamilien · Optimierte time lags

Partisan theory - the main premise of which is that the ideological positions of parties forming the government have an impact on policies and policy outcomes-is the workhorse in comparative politics. This systematic connection has been confirmed in various policy areas (Potrafke 2017; Zohlnhöfer et al. 2017). In recent years, however, this causal relationship has been called into question (Häusermann et al. 2013). With the erosion of traditional consistencies and the diminishing importance of the left and right dimensions, the direct influence of left and right parties on policies and outcomes is being undermined. We argue in this paper that the left-right dimension and party family theory are two separate concepts and that their combination has led to confusion about the causal relationship between government positions and outcomes. The separation of the two concepts is particularly important when it comes to environmental issues. Environmental issues are hard to frame within the canon of the established party family approach (see Töller in this special issue). Some studies confirm a systematic influence of party differences on environmental issues (Jensen and Spoon 2011; Ward and Cao 2012) whereas others do not (Scruggs 1999).

Much of the confusion arises from a cursory reading of Hibbs' (1977) seminal study. Although he connects left and right parties with left-right positions, his study also implies that center parties can be placed on a different political dimension. Klaus von Beyme (1985, p. 136), who developed the party family approach, comes to the same conclusion. He describes that nationalization and strengthening of the state sector can be combined with left positions and law and order with right positions: "But there are demands in other areas which can well pay a greater part in day-to-day political activity, such as social policy, energy policy or environmental protection, and they can only be forced into a Left-Right pattern with some distortion." This assumption is supported by political theory, which says that a green ideology is 
neither left nor right, but rather based on the opposition between environmental protection and economic growth (Dobson 2007; Humphrey 2013).

Much of the confusion between left and right positions and party families is due to the classification of data sets that are widely used in macro-comparative studies (Armingeon et al. 2020; Cruz et al. 2021; Swank 2018). In these data sets, all parties in a party system are classified in left-center-right, which suggests a onedimensional scaling of the parties on the left-right scale. We will show that this simplification is not appropriate for empirical studies that focus on topics that do not fall into this classification. Instead, we use the new PACOGOV data set, which distinguishes between ten party families, to analyze the influence of party families on environmental outcomes (Schmidt et al. 2020).

This paper examines the influence of party families on greenhouse gas emissions (GHGEs). GHGEs are mainly responsible for global warming and empirical studies on broader environmental challenges have shown that there has been far less progress on combating GHGEs compared to improving other environmental conditions. Therefore, GHGEs may be labeled as a hard environmental issue (Bernauer 2013; Jahn 2018; Klagges 2019).

The results show that the trichotomy of left-center-right does not contribute much to the explanation of differences in GHGEs. A more fine-grained analysis of party families shows that only green parties have an unambiguous effect in that their government participation corresponds with diminishing GHGEs. In contrast, secular center parties have a significant negative effect on GHGEs when in government. The right parties are not the major government parties showing the poorest GHGEs performance. That shows that we cannot place GHGEs on a left-right policy dimension. However, the empirical analysis also shows that the effects of government parties are not instant but that they often need more than two years to show substantial impacts. This methodological aspect is often neglected in macro-comparative studies and is integrated into our analysis using optimized time lags.

In the next part of the article, the concept of partisan theory is discussed from the perspective of the party family approach. In this context we refer to the theory of organizational institutionalization in party research. What follows is the formulation of hypothetical effects of different party families on GHGEs. The third part outlines the design of the empirical study. The fourth part reports on the results and the conclusion discusses the results in a broader context.

\section{Partisan theory and party families}

The classical partisan theory takes the left-right dichotomy as the starting point of its analysis and classifies government parties into the categories of left and right (Hibbs 1977; Tufte 1978; Cameron 1978; Stephens 1979; Schmidt 1982). The theory is based on the assumption that political parties implement a policy outcome that corresponds to their ideology or preferences. Hibbs (1977, p. 1471) offers a list that left parties favor above all full employment and equality of income distribution. Still high on the left agenda is economic expansion, in contrast to price stability and balance of payments equilibrium which are lower on the list. This is different for right 
parties which place price stability highest. Economic expansion and full employment get a much lower score. Interesting in our context is that Hibbs also offers a list for center parties which favor price stability the most-but less so than right parties. Furthermore, these parties see economic expansion and full employment as more important than right parties. This list shows that in the 1960s when this survey was conducted, economic expansion is most important for left parties, followed by center parties and finally by right parties. We can learn two things from Hibbs' classification: first, left and right are two opposite positions but center parties do not fit neatly in the middle of this scale. Second, the left took the strongest economic growth position, followed by center parties leaving right parties as the least economic expansionist parties.

Despite the ideological trichotomy, partisan theory focuses on the left and right dichotomy. The reason is that Hibbs' empirical analysis combined this left-right orientation of parties with the Philips curve which sees a trade-off between inflation and unemployment. Left parties fight against unemployment and tolerate inflation at the expense of achieving economic growth. In contrast, right-wing parties prefer price stability to addressing issues of unemployment. That means that Hibbs ignored the distinct difference of center parties, which is completely appropriate for his analysis, but which causes substantial problems when applied to other issues.

However, Hibbs' concept of rational parties can also be employed to other classes of parties. The first step has been to include the class of center parties. As Schmidt (1996, p. 160) states, center parties favor a "moderate social amelioration in a location to the left of conservative or conservative-neoliberal parties." According to this view, the center-as the name suggests-lies between left-wing and right-wing parties. That means that partisan theory does not have to dismiss the left-right dimension but just adds another party type in the middle of this scale. However, this simple model might be inappropriate. The "center" may not be between left and right but may rather represent another policy dimension. This becomes evident when we look for instance at the classification of welfare states. As Esping-Andersen (1990) and even more so van Kersbergen (1995) show, "center" parties do not create policies in the middle of left and right but rather another kind of welfare state. That means that center parties would not be placed on a one-dimensional left-right scale but that the policy space is multi-dimensional. This argument can be elaborated when we consider party families on a multi-dimensional space. In this view, party family theory is an alternative approach to look at the rational policy model of Hibbs. Instead of looking at the left-right dimension it takes the various formative moments and historical development of political parties into account (Beyme 1985; Ware 1996). Klaus von Beyme (1985) shows that the emergence of new parties is a reaction to other parties or to social trends. His extensive historical analysis can be very roughly summarized as follows:

1. Liberal parties emerged as a reaction against the old regime (autocracy).

2. Conservative parties entered the scene to defend the old regime against the attacks of liberal parties.

3. Labor parties emerged in order to overcome bourgeois societies. 
4. Agricultural parties were formed against the process of industrialization and urbanization.

5. Regional parties developed in opposition to centralization and the dominance of the nation state.

6. Christian parties opposed the process of secularization.

7. Communist and socialist parties were directed against the reform and consensus approach within the labor movement (against social democratization).

8. Fascist parties were against democratic systems and internationalization.

9. Right-populist parties opposed bureaucratization and expert rule.

A missing party group in the von Beyme's classification are green parties which became relevant forces in the 1980s and which oppose increasing environmental degradation and now belong to the group of established parties (Müller-Rommel 1989; Jahn 1993; Dalton 2009). Not all party families survived or became relevant government parties in modern democracies. Parties develop over time in specific ways depending on changes of the socio-political environment and their electoral fortune. In some countries for instance, mainly outside Western Europe, secular center parties emerged in opposition to conservative parties instead of social democratic parties.

To be clear the party family approach originally had nothing to do with the left-right dimension. Only later did some authors begin offering empirical data (Armingeon et al. 2020; Cruz et al. 2021; Swank 2018) combining the party family approach with the left-right dimension, leading many to believe that the left-right policy dimension is inherent in the party difference approach. However, using such a perspective gives up a lot of important distinctions of party differences. The party family approach is multi-dimensional since it refers to societal conflicts and formative moments of the emergence of political parties.

The party family approach refers to the formative ideological standpoints which are shaped in the early years of a party and which are crucial for the position that parties take in political systems. That does not mean that parties do not respond to new problems or modify their previous positions. The question is, of course, to what extent these formative positions still influence the current policy choices and whether the concept of party families can explain differences in politics and outcomes (Häusermann et al. 2013; Jun and Höhne 2012). ${ }^{1}$ Angelo Panebianco's (1988) approach of party institutionalization offers a theory of organizational evolution. This is not a deterministic theory but rather postulates that the evolution of parties "... varies from party to party and depends on numerous factors, above all, ... the party's organizational history and the features of the 'environments' in which it operates." (p. 17).

According to the approach of party institutionalization, parties emerge because of a common cause. Around this common cause an ideology is formulated which

\footnotetext{
1 One way to analyze the impact of partisan theory in a more dynamic perspective is to analyze changing party positions (McDonald and Budge 2005; in the field of environmental performance see: Jahn 2018). However, this would imply another research question than looking at the effects of party families (Zohlnhöfer 2020).
} 
determines political action. In this formative stage, party action can be interpreted with a closed rational model of organization theory where party ideology explains policies. This model is the approach Hibbs used in his explanations. However, parties institutionalize and with increasing maturity the major aim of a party is not entirely or even mainly the common cause or the formative ideology anymore but rather the organizational survival and the counter-balancing of particular interests within the party. That means that parties function according to the open natural system model of organizational theory and that they adapt to the requirements of the environment. Important in our context, the room to maneuver is still determined by the party ideology. That means that the causality between ideology and policy can still be perceived as in the rational model but that contingent factors caused by various environmental requirements dilute this direct causality. Therefore many studies dealing with the impact of parties on environmental performance identify several conditional effects (Abou-Chadi 2014; Anderson 2001; Chang et al. 2018 Jahn 2018; Lim and Duit 2018; Spoon et al. 2014). In this study we estimate the strength and limits of the rational model. However, we depart from the assumption that the left-right dimension is an integral part of the partisan theory and focus instead on the historical development of party families.

\section{Party families and their positions on mitigating climate change}

A detailed analysis of party evolution would require ideographic studies of any single party in a political system. Klaus von Beyme's general historical analysis comes close to such an approach and although Panebianco's ideal typical analysis is more rigid, in his empirical analysis he gives many ideographic examples. The value of ideographic analysis is limited because there are countless intervening variables and generalizable conclusions are difficult to be drawn. In the following analysis we focus on the ideological connections from various party families to environmental positions. We refer to environmental policy positions here because we consider climate change mitigation to be an environmental issue. Although environmental politics is a relatively new phenomenon in political systems, it has a tradition of more than four decades. The debate on climate change, although recent, is a part of environmental politics, and therefore the environmental policy positions of party families are important to understand their stance on climate change. However, we refer here to general positions, as we know that there are also dissenting cases.

The main party families that have been involved in governments for long periods of time are the social democratic, Christian and non-Christian center, conservative, liberal, communist, socialist, and green parties. When considering partisan effects, it is most likely that green parties have a positive effect of reducing GHGEs. This is because green parties have been founded in order to fight environmental degradation (common cause). That means that the formative moment of green parties focuses on environmental issues. Furthermore, green parties are still young organizations, and they have not reached the status of maturity although they are institutionalized in most countries. That means that the rational model is most likely applicable and that the link between party ideology and policy position is rather straight forward. How- 
ever, even for green parties the complexity of GHGEs is a challenge. Many green party voters live in suburban areas, needing a car for commuting and are eager to travel abroad. Measures to reduce GHGEs through price increases of energy, gasoline or meat products, etc. may alienate some green party supporters. Nevertheless, we assume that governments with green parties have a significant GHGE reducing effect. For all other party families, the situation is much more ambiguous because they are mature organizations (perhaps with the exception of some populist parties) and must therefore be analyzed according to the natural system model. Since environmental issues such as climate change are valence issues, we may assume that in fact all parties are for a reduction of GHGEs. However, they may differ in the degree to which they support measures against GHGEs or which stand they take when economic interests are affected.

The formative ideological core of left parties is social equality (Bobbio 1996). Embedded in Marxist ideology, societal change is to be achieved by technological progress and economic expansion. The left ideology is an ideology of industrial society and enlightenment. In this perspective the formative left ideology does not give environmental concerns much attention. However, left parties may take an environmental position referring to social equality. Workers and their families are often living downstream from polluting industries suffering from the consequences of environmental degradations. More than this, the constituency of successful left parties has expanded to white collar workers. This group of the electorate has grown over the years and simultaneously the group of traditional workers diminished (Kitschelt 1994; Gingrich and Häusermann 2015). Through this structural change-but not out of ideological reasons-left parties adopted environmental positions because white collar workers are often more environmentally concerned than traditional workers. The responsiveness to environmental positions is particularly strong for weak left parties. Small left radical parties often moved from socialist or communist parties to so-called left-libertarian parties with a strong environmental profile (Kitschelt 1988). Probably most strongly of all parties, social democratic parties have to find a balance between traditional goals of economic expansion and environmental demands (Kitschelt 1994). They aim to keep their catch-all party image by trying to tap into groups of white collar voters. However, by doing so they often alienate their former core voters. It also shows that weak social democratic parties or social democratic parties in opposition like the German SPD have integrated more of the earlier environmental positions into their program than strong social democratic parties like the SAP in Sweden. These considerations of the environmental positions of left parties lead to the hypothesis that left parties may have opened their program for environmental concerns but to a much lower degree than green parties. Because these ideological shift dependents on specific socio-political circumstances we expect a high variation among left parties. This may be particularly true of communist and socialist parties, as some moved to ecologically open left libertarian parties and others remained traditional left-wing parties with low environmental concerns.

Center parties encompass a vast group of parties. One can divide this group into Christian parties and secular center parties. Christian parties often have a view on nature that it is created by God and should be held in respect. Knill et al. (2010, p. 304) state: "Christian democratic party family or other parties that stress religious 
aspects, the protection of the environment might be important in terms of saving 'God's creation'." On the other hand, Christian democratic parties have become strong government parties in many countries. Government responsibility led them to become parties that advocated economic interests and supported large industries. In fact, Christian center parties often take the position of conservative parties in political systems where conservative parties do not exist. This aligns them closely to industry and big business and therefore they are less prone to follow a radical environmental agenda.

Non-Christian center parties are agricultural or farmers' parties in some countries, mainly in the Nordic countries but they also exist in France in form of the President Macron La République on Marche or the Parti républicain. In Japan the Komeito, and in North America the Democratic Party in the United States belongs to this party family. These parties were mainly founded as opposition to right-wing parties in countries where left-wing parties are weak or not at all established. In the Nordic countries, the peasant movement gave rise to strong agrarian parties that opposed the old regime. In these countries they joined together with social democratic parties to form a red-green alliance that made the Nordic welfare states possible. Due to land use by farmers, agricultural parties are interested in using environmental resources sustainably. As non-Christian parties are very diverse it is difficult to predict which stand they take on environmental issues. It seems that most of these parties are quite open to environmental questions. The center parties in the Nordic countries were often leading in this respect. Above all, the Swedish Center Party and the Democrats in the United States give environmental issues high priority. On the other hand, it may be questionable whether non-Christian parties forego economic expansion for environmental reasons. The Center Party's support for the extension of nuclear power in Sweden and the growth orientation of the Democrats in the United States support the highly expansionist image of the center parties.

Liberal parties may be less open for environmental issues because of their relation to small business owners and the self-employed. Liberal parties emerged because they wanted to create free markets in which entrepreneurs could pursue their economic interests unhindered. However, in historical perspective one can see that liberal parties are quite responsive to new trends (Smith 1988; Dalton 1991). For instance in the 1970s liberal parties were the first established parties to open up to environmental concerns (Jahn 2000). In some instances, social liberal parties may even support stricter climate change regulations than other parties (Cetkovic and Hagemann 2020). However, liberal parties change their positions-sometimes fundamentally - depending which faction in the party dominates. The German FDP changed from a social to a neo-liberal party in the early 1980s and the Austrian FPÖ changed from a liberal to a right-wing populist party. This makes it difficult to predict the impact of liberal parties on GHGEs.

Conservative parties can also take an ambiguous position on environmental issues. The main aim was to prevent social change and to preserve the traditional order. That said, conservatism also means preserving nature. This traditional understanding of nature lost its relevance in the course of history when conservative parties switched to a party family that supported big industry. Similar to Christian center parties, conservative parties were often given government status and were thus responsible 
Table 1 Hypothetical Position of Party Families Concerning Combating Greenhouse Gas Emissions

\begin{tabular}{lll}
\hline Party Family & \multicolumn{2}{l}{ Combating Greenhouse Gas Emissions } \\
& Strength of pro and con arguments & Overall Assessment \\
\hline Green Parties & $+++/-$ & +++ \\
Communist and Left Socialists & $+++/--$ & ++ \\
Social Democrats Parties & $++/--$ & + \\
Christian Parties & $++/--$ & + \\
Conservative Parties & $+/--$ & -- \\
Nationalist and Right Populist Parties & $+/--$ & -- \\
Liberal Parties & $+/---$ & -- \\
Non-Christian Center Parties & $+/---$ & - \\
\hline
\end{tabular}

for economic expansion. This brought conservative parties close to the interests of big business. All of this speaks for strong support for an expansion policy and little interest in environmental protection. However, some conservative voices calling to take environmental issues more seriously. Most famous in this context is the speech of the British Prime Minister Mrs. Margret Thatcher to the UN in 1989 where she demands more efforts to prevent climate change.

Nationalist and right populist parties have been founded to protect "people" against the state elites. This is true for the older populist parties which opposed above all state bureaucracy but it is also true for the newer right-wing populist parties which protest against migration. Even if nationalist and populist parties oppose the contemporary state they support the nation. Concerning environmental protection they have a traditional nationalist perception which supports national heritage and glorifies the homeland or native country. More science-based environmental issues such as climate change are not high on the agenda for those parties or they are even vehemently opposed. Climate change is often questioned altogether and is framed within conspiracy theories (Brown 2014; Lockwood 2018). Populist parties are a new phenomenon and their emergence is likely to correspond with a tightened environmental policy so that no clear connection can be predicted (but see Jahn 2021).

Regarding the party families from a green versus growth continuum one may place the parties according to Table 1 . The Table gives a rough estimation of the extent to which there are arguments that a party family combats climate change (+) and how strong counter forces are present in the party (-).

These hypothetical positions deduced from a historical analysis of party families is by and large supported by Farstad's (2018) current analysis of climate change salience in party manifestos. In her study, ecology parties emphasize climate change more than twice as much as all other parties. Second are communist, social democratic, Christian democrats and conservatives, leaving liberal, national and agrarian parties at the end. On general environmental issues, Carter (2013) postulates that established parties' responses are modest and strongest among social democratic parties which compete with green parties in their party system. Jahn (2018, pp. 209-214) comes to similar results and also sees social democratic parties-besides green parties-as those most open to environmental concerns. However, he also finds a sub- 
stantial difference when social democrats are in power or opposition. In government, social democrats emphasize much fewer environmental issues than when they are in opposition (see also Neumayer 2003).

\section{Empirical analysis}

Our research objective is to estimate whether party families in government make a difference in GHGEs. The dependent variable is the annual change of GHGEs measured in kilograms per capita. ${ }^{2}$ In order to answer this question we analyze partisan effects in 21 highly industrialized democracies between 1990 and 2018. ${ }^{3}$

Our independent variable is the strength of the party families in government. As an indicator, we will first use the trichotomy by Armingeon et al. (2020). He distinguishes left (communist, socialist, green, social democrats), center (Christian democrats, agricultural and other center parties) and right parties (liberal, conservative, nationalists). This classification is probably the most widely used in macrocomparative studies and suggests that party families can be measured on a left-right scale. Second, we use the new PACOGOV data set for a more detailed analysis of party families (Schmidt et al. 2020). This data set builds on von Beyme's concept of party families and distinguishes between ten party families. The strength of party families is measured as percentage of ministries from a specific party family in relation to the total number of ministers.

As a control variable we use corporatism, a key variable in macro-comparative environmental studies (Crepaz 1995; Jahn 1998; Scruggs 1999, 2001, 2003) and a shortcut concept for Lijphart's patterns of democracy; (Anderson 2001; Roller 2005). Corporatism is operationalized as a time-variant variable (Jahn 2016).

Other strong predictors of GHGEs have less to do with short or mid-term political decisions. One major driving force for GHGEs is the use of fossil fuels (coal, oil, gas). We predict that an annual increase or decrease of fossil fuels has a direct effect on changes in GHGEs. ${ }^{4}$ The data are taken from the BP database and standardized for energy consumption in kilograms per capita.

Finally, we control whether economic growth has an impact on GHGEs. This seems to be likely because economic growth is often associated with increasing production, which causes higher pollution. However, it is an established conviction of the ecological modernization school that the nexus between economic growth and pollution is decoupled (Jänicke and Jacob 2007; Mol et al. 2009; Young 2000). We

\footnotetext{
2 Total GHGEs include carbon dioxide, methane nitrous oxide, unspecified mix of hydrofluorocarbons and perfluorocarbons, sulfur hexafluoride, and nitrogen trifluoride, excluding land use, land-use change and forestry (LULUCF). Data are taken from the OECD; June 18, 2020.

3 We include all relevant (more than a million inhabitants), rich and established democracies: Australia, Austria, Belgium, Canada, Denmark, Finland, France, Germany, Greece, Ireland, Italy, Japan, the Netherlands, New Zealand, Norway, Portugal, Spain, Sweden, Switzerland, the United Kingdom, and the United States. The time period is determined by the availability of data on GHGEs.

4 We also tested models including nuclear, wind, solar and renewable energies. The effects of these variables have been swallowed by the fossil fuels variable and the substantive results for party effects were the same as with the parsimonious model applied in this paper.
} 
include the percentage annual change of Gross National Income. The descriptive statistics of the variables are provided in the appendix.

The model is a panel corrected standard error regression (xtpcse) which specifies that within panels there is first-order autocorrelation AR(1) (Beck and Katz 1995). In all models we include year dummies to account for temporal effects. However, including dummy variables for countries (fixed effects, FEs) is more of an issue because the models probably have a better estimation when including FEs but FEs wipe out all country differences (Mummolo and Peterson 2018; Plümper et al. 2005; Plümper and Troeger 2019), which is not desirable from a substantive point of view because we are interested in country differences in explaining changes of GHGEs. In order to capture the short-term effect of party families in government, we apply a first difference model in which all variables are included in the model with their annual changes.

Since the causal mechanism between the influence of government position (and most of the other political variables as well) is not instantaneous, we use the newly established technique of optimized delays (Jahn 2021; see also Cranmer et al. 2017). The common standard in macro-comparative studies is to use a time lag of one year. This is applied no matter if it concerns government decisions, the impact of EU regulations, or the impact of structural changes. However, Janoski and Isaac (1994, pp. 35-36) estimate that the delays in different policy areas vary considerably and that the normal legislative lag is between one and three years. The inclusion of the implementation period is conceivable in order to extend this time delay by one year. Empirically, Plümper et al. (2005) show that the optimization of the lag structure for a certain variable leads to significantly different regression coefficients and confidence intervals. They conclude: "Though the optimization of lags is certainly time consuming, it is absolutely essential in first difference models" (Plümper et al. 2005, p. 344). We optimize the time lags of the two political variables: party families and corporatism. The structural variables contained in the model act immediately and therefore we apply no time lag. In order to identify the optimized lag structure of a variable in a specific country, each variable is tested with various lags for each country. This is done by keeping all but one country with no time lags. For each country, all possible combinations of analytically set ranges of time lags were tested. As an effectiveness criterion, R-squared is used. In the next step, the same procedure is applied for all other countries. The equation of our model is as follows:

$$
\begin{aligned}
& \Delta \text { GHGEs }_{\text {IT }}=\alpha_{0}+\beta_{0} \text { GHGES }_{\text {it }-1}+\beta_{1} \Delta \text { PARTY FAMILY }_{\mathrm{it} 1-4} \\
& +\beta_{2} \Delta \text { CORPORATISM } M_{\text {it } 1-4}+\beta_{3} \Delta \text { FOSSIL FUELS } \\
& +\beta_{4} \text { ECONOMIC GROWTH }+\beta_{\mathrm{yi}} \text { YEAR EFFECTS }+\varepsilon_{\mathrm{it}}
\end{aligned}
$$

The term $\triangle$ GHGEs it represents the dependent variable $\mathrm{Y}$ in each country $\mathrm{i}$ and each year t. $\mathrm{Y}$ is measured as first difference $(\Delta)$. The variable GHGEs it-1 is the one-year lagged level of the dependent variable. This variable controls the level at which changes occur, as countries with high emissions may have a greater potential to reduce emissions. If so, we expect a significant negative correlation. $\triangle$ PARTY FAMILY is the first difference of the proportion of cabinet shares of a respective party family in country $i$ with a time lag between one and four years. 
$\triangle$ CORPORATISM has been modelled in the same manner. $\triangle$ FOSSIL FUELS and ECONOMIC GROWTH have no time lag because we assume that their effect is instant. All models include a dummy variable of all years in order to control for temporal changes and yearly shocks (YEAR EFFECTS). The error term $\varepsilon_{i t}$ captures the unexplained variance in the model and, $a_{0}$ is the intercept.

We use a first difference model which has several advantages. First of all, it fits the theoretical assumption that when parties come to power, outcomes change. From a methodological point of view, first difference models overcome the omitted variables problem with panel data more efficiently than fixed effects models (Wooldridge 2000, pp. 447-448).

\section{Results}

We begin our analysis by estimating the party effects on GHGEs on a left-right dimension. For that we use the trichotomy of left-center-right parties. In this analytical step we also address the effect of time in our models. Table 2 shows the results once with a time lag of one year which is the common standard in macrocomparative analysis. The next three models show the results with optimized lags for party families and corporatism.

The results show that party families do not have a significant impact on changes in GHGEs with a standard lag of $\mathrm{t}-1$ (models 1 to 3 ). The only exceptions are

Table 2 The Impact of Left, Center and Right Party Families on Greenhouse Gas Emissions without and with Optimized Time Lags

\begin{tabular}{lllllll}
\hline & $(1)$ & $(2)$ & $(3)$ & $(4)$ & $(5)$ & $(6)$ \\
& Left & Center & Right & Left & Center & Right \\
& No optimized lags & & With optimized lags & \\
\hline GHGEst-1 & $-0.00554^{* *}$ & $-0.00557^{* *}$ & $-0.00553^{* *}$ & $-0.00555^{* *}$ & $-0.00553^{* *}$ & $-0.00548^{* * *}$ \\
& $(-3.01)$ & $(-3.01)$ & $(-2.99)$ & $(-3.11)$ & $(-3.10)$ & $(-3.00)$ \\
$\Delta$ PARTY & -0.0802 & $1.182^{*}$ & -0.363 & $-0.708^{+}$ & $1.340^{*}$ & -0.0519 \\
FAMILY & $(-0.20)$ & $(2.12)$ & $(-0.96)$ & $(-1.75)$ & $(2.30)$ & $(-0.14)$ \\
$\Delta$ CORPORATISM & 22.36 & 23.25 & 11.17 & 69.91 & 73.23 & 68.68 \\
& $(0.27)$ & $(0.28)$ & $(0.14)$ & $(0.95)$ & $(1.00)$ & $(0.94)$ \\
ECONOMIC & 1.003 & 1.046 & 0.946 & 1.244 & 0.512 & 0.912 \\
GROWTH & $(0.22)$ & $(0.23)$ & $(0.20)$ & $(0.27)$ & $(0.11)$ & $(0.20)$ \\
$\Delta$ FOSSIL & $271.9^{* * *}$ & $272.6^{* * *}$ & $271.8^{* * *}$ & $268.5^{* * *}$ & $267.7^{* * *}$ & $270.8^{* * *}$ \\
FUELS & $(28.89)$ & $(29.12)$ & $(28.91)$ & $(28.13)$ & $(27.81)$ & $(28.24)$ \\
_cons & $98.19^{* * *}$ & $97.65^{* * *}$ & $100.0^{* * *}$ & $104.5^{* * *}$ & $105.6^{* * *}$ & $101.1^{* * *}$ \\
& $(3.90)$ & $(3.89)$ & $(3.97)$ & $(4.32)$ & $(4.34)$ & $(4.07)$ \\
$N$ & 588 & 588 & 588 & 588 & 588 & 588 \\
r2 & 0.787 & 0.789 & 0.788 & 0.789 & 0.790 & 0.788 \\
Adjusted_r2 & 0.775 & 0.777 & 0.775 & 0.777 & 0.777 & 0.775 \\
$\varnothing$ Time Lag & - & - & - & 2.80 & 2.51 & 2.45 \\
\hline
\end{tabular}

Explanations: $t$ statistics in parentheses; ${ }^{+} p<0.10,{ }^{*} p<0.05,{ }^{* *} p<0.01,{ }^{* * *} p<0.001$; period effects (year dummies) included in all models but not shown. 
center parties which have a negative effect on GHGEs. $\triangle$ CORPORATISM as well has no significant impact. In these models, $\triangle$ GHGES are mainly explained by the use of $\triangle F O S S I L$ FUELS: an increase in fossil fuels by one ton per capita leads to an increase in greenhouse gases of $272 \mathrm{~kg}$. The high R-squared also shows that we have included variables that have a strong impact on changes in GHGEs. ${ }^{5}$

The analyses with optimized lags (models 4 to 6 ) show some partisan effects. Left party families are associated with a reduction in GHGEs by $0.71 \mathrm{~kg}$ per one percent higher share of ministers. That means that a change from a non-left to a single party left majority government reduces GHGEs by $71 \mathrm{~kg}$. This result is significant at the $p<0.1$ level. The finding that right party families have no significant impact on GHGEs but center parties have a strong negative effect confirms that center parties are most expansionist and that the left-right dimension is not conclusive for the prediction of GHGEs. This effect is twice as strong as for left party families and significant at the $p<0.05$ level. The duration between changes of government composition and GHGEs is around two and a half years for all party families.

$\triangle$ CORPORATISM has no significant effect even when applying optimized lags. This result shows that optimizing lags do not lead necessarily to significant results. In models 4 through $6 \triangle$ FOSSIL FUELS and ECONOMIC GROWTH do not change their effects considerably. The coefficient for the former diminishes only slightly, and although the coefficient for the latter increases, it remains far from being significant.

The results so far suggest that changes in GHGEs do not neatly fall together with the left-right dichotomy. While it is true that left party families coincide with a reduction in GHGEs, right party families are not on the opposite side. The opposite pole is rather formed by the center parties. Interestingly, this finding is similar to Hibbs's assessment that the parties in the center are more in favor of economic expansion than the right-wing parties. Does that mean that the powerful Christian

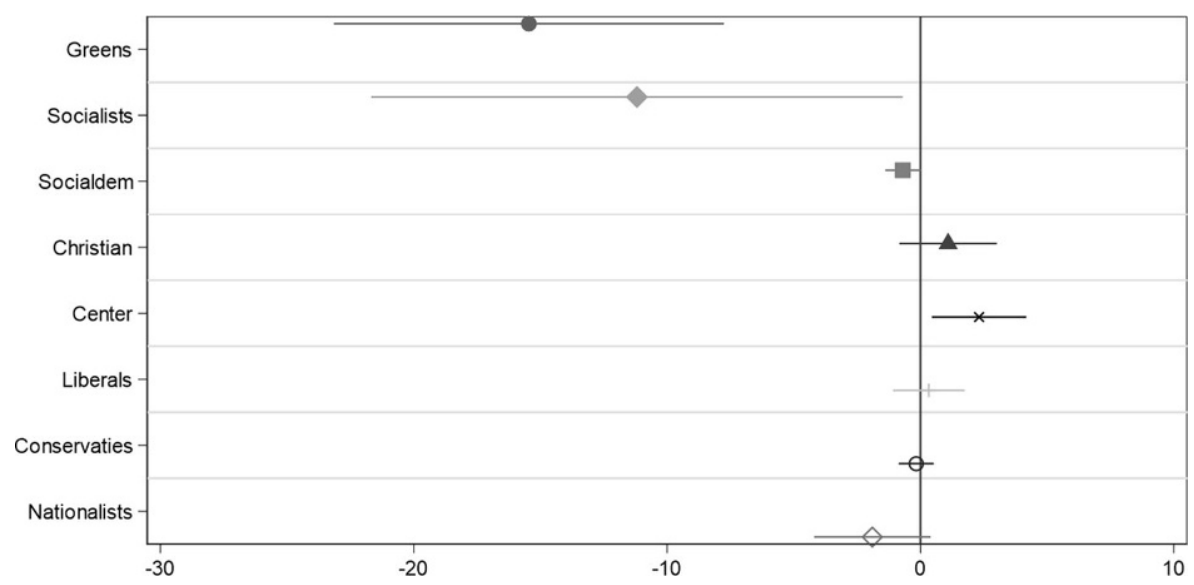

Fig. 1 The Impact of Party Families on Changes in Greenhouse Gas Emissions. Explanations: Coefficients for each party family are from different models shown in the appendix. Confidence interval is at the 0.9 level

\footnotetext{
5 This high R-squared is driven by $\triangle$ FOSSIL FUELS.
} 
democratic parties of continental Europe foster GHGEs? In the next step we turn to this question by disaggregating the party families.

In Fig. 1 we show the results for the eight party families as described above. In particular we disaggregate the class of left party families into green, communist and left-socialist and social democrats respectively. For center party families we distinguish, on the one hand, religious center parties and, on the other, secular center parties. The right party family is disaggregated into liberal, conservative and nationalist parties. All models use optimized lags for party families and corporatism. The results for the other variables correspond with models 1 through 6 above and are therefore not further interpreted in the following. For the regression model see Table A2 in the online appendix.

Basically, the results confirm the findings above, but they show that we should be cautious when aggregating party families. ${ }^{6}$ That left-wing party families reduce GHGEs is only true unambiguously for green parties. ${ }^{7}$ For green parties we find a substantial and significant $(p=0.001)$ effect for a reduction of GHGEs. ${ }^{8}$ When green parties gain a one percent higher share of ministers GHGEs fall by $15.5 \mathrm{~kg}$. With an average cabinet size in Western European countries of around 20 ministers (Indridason and Bowler 2013), one additional minister for a green party leads to a reduction in greenhouse gases by $77.5 \mathrm{~kg} .{ }^{9}$ For communist and left-socialist parties which partly belong to environmentally friendly left-libertarian parties, we also find a substantial effect (56 kg reduction of GHGEs per minister), but this effect is only significant at $p=0.079$. The huge confidence interval shows that communist and socialist parties differ depending on whether they turn into left-libertarian parties or remain orthodox left-wing parties. For social democratic parties, which are by far the most dominant government party within the left party family group, the effect is much more modest and only significant at $p=0.098$. Here a change of one minister reduces GHGEs by only $3.5 \mathrm{~kg} .{ }^{10}$

For the center party family we identify different effects for Christian democratic parties and secular center parties. It shows that only the latter has a negative impact on reducing GHGEs. These parties are strong in poorly performing countries such as the United States, but also in the better performing Nordic countries. In particular in the latter countries secular center parties adopted environmental issues but envi-

\footnotetext{
6 The results are robust (Neumayer and Plümper 2017). The analysis including fixed effects shows slightly lower coefficients and significant levels. For social democratic parties that means that we do not find a significant effect when we control for country differences. For secular center parties the significance level drops to $\mathrm{p}=0.068$. For green parties the significance level is still $\mathrm{p}<0.05$. See online appendix Table A3.

7 One can dispute that green parties are left parties by definition. In fact empirically that does not hold true for all advanced democracies (see for this instance Jahn 1993).

8 This effect is retained when various robustness tests are applied. Jackknife tests and bootstraps increase the coefficient but decrease the level of significance. This is particularly evident when one checks country effects.

9 Of course, this is only an illustrative calculation. In countries where the minister principle dominates, green parties often receive the position of the environmental minister. So a change to a green party in government would have a substantially higher impact.

10 The results are not robust, so it is better to conclude that social democratic parties have no effect on GHGEs in our sample of highly industrialized OECD countries (see Table A9).
} 
ronmental positions are not deeply rooted in the party 's ideologies. This is why Jahn (2000, pp. 188-198) called these parties "secondary environmental parties" because their formative ideological standpoints do not include an environmental position, as is the case with green parties. One more minister for non-Christian center parties is associated with an increase of $11.55 \mathrm{~kg}$ of GHGEs. This result is significant at the $p=0.04$ level. ${ }^{11}$

For right-wing party families we cannot add much to the former findings. Neither liberals, conservatives nor nationalist and populist parties have a significant effect on GHGEs.

Optimized time lags identify how long it takes until a party family has an effect on changes in GHGEs. As mentioned above, that was around two and a half years for the trichotomized left-center-right category. Disaggregating the time lags shows the exceptional position of social democratic parties within the left party family camp. For social democrats the time lag is 2.74 years, for greens 2.46 and for leftsocialists 2.22. For the non-religion center parties it is the opposite. Their time lag is 2.91 years and therefore considerably longer than for left parties. In view of these time lags, it is not surprising that many authors were unable to determine any party effect when using only the $\mathrm{t}-1$ standard (for testing different time lags see appendix Tables A4-A6).

\section{Conclusion}

The paper shows the strengths and limitations of partisan theory in the field of environmental performance. The assumption that parties make an impact once in government is often closely related to the left-right dimension. We have argued here that this is not a necessary requirement of partisan theory. The causal mechanism is that party ideology are predictors of party actions. Such a direct association perceives parties as closed rational systems. However, during their organizational institutionalization, parties increasingly focus on their self-interest in survival. This causes parties to adapt to their environment. This perception regards parties as open natural systems. In other words, the formative ideology is still relevant, but does not determine political action to the same extent as in the formative period. Programmatic positions change party-specifically and require detailed case studies. In order to be able to carry out a macro-comparative analysis with the potential to make generalizable statements, we have resorted to the party family approach, which explains the party position on the basis of the formative ideology and typical programmatic adjustments of party families. The advantage of referring to party families instead of focusing on a single left-right dimension is that, firstly, we can better distinguish where a party is in terms of its institutionalization, and, secondly, that we understand party behavior in a multidimensional space. The latter point is important for topics that do not fit neatly into the left-right semantic such as the environment or GHGEs.

11 The robustness test (Table A11) shows that this result is not robust and that the result is driven by specific observations and countries. 
The analysis in this paper makes it strikingly clear that green parties are the only party group with a clear influence on GHGEs. This is because the formative ideology of green parties is still alive due to their relatively weak institutionalization and the common cause is the ongoing fight against environmental degradation. In this respect, green parties can best be interpreted using the rational organization theoretical model.

For all other parties we have to use an open natural organization model and ask to what extent the formative ideology is still effective and to what extent this ideology supports or hinders an attitude towards reducing GHGEs. The results show that there is still a causal connection between the formative ideologies. This applies in particular if we deviate from a strict left-right positioning of the parties. We found-like many other studies - that left parties are more effective in reducing GHGEs, but we also saw the center parties, not the right parties, as antipodes. This finding is consistent with the historical party family analysis and contradicts a simple left-right interpretation.

Such a study, which is based on different organization theories, is only possible if we are able to disaggregate party families in sufficient detail. The classification of communist and socialist, social democratic and green parties into the category of a left party family prevents an explanation based on a historical evolution of party families. We therefore adopted a more fine-grained approach to party families.

Indeed, we have analyzed the effect of party families on GHGEs in terms of rational organization theory. This perspective does not tell the whole story. However, it shows how the organizational roots still affect current issues. This is important to know because the formative ideology of a party has a lasting effect. As Allan Ware notes, parties are "prisoners of their own history as an institution" (Ware 1996, p. 18). An organization theoretical analysis that perceives political parties as open systems that react to their environment would complement our explanation. There are many studies that explain environmental positions and outcomes in terms of conditional effects (Abou-Chadi 2014; Anderson 2001; Chang et al. 2018; Lim and Duit 2018). However, each of these studies focuses on interesting aspects and examines how they interact with ideological variables. The conglomerate of different explanations of often arbitrarily chosen conditional effects could be structured by applying organizational theory. An organization theoretical approach could provide better guidance for structuring these analyses and provide deeper insights into party behavior. There are some studies in other areas that have developed the concept of "constrained partisanship" but have not yet been applied in the field of environmental policy (Beramendi et al. 2015; Manow et al. 2018).

Another important result of our study is that partisan effects cannot be recognized immediately or with a time lag of one year. The political process is complex and takes time. The time frames vary depending on the country and the problem, so we need a flexible approach to model such a situation. We used optimized time delays, which is an inductive approach. This is certainly not the best way to grasp time effects but is still better than applying unrealistic concepts such as the t- 1 standard. Until we develop a theory of the time of the political process, inductive analysis is the only way to consider the effects of time on outcomes. Modeling time lags is certainly an important topic for macro-comparative analysis of the future (Cranmer 
et al. 2017; Jahn 2018, pp. 38-41). Combining case studies analyzing the time lags in politics and macro-comparative studies would be a promising way of developing a theory of time in politics and would turn atheoretical time lags into theoretical time lags.

Supplementary Information The online version of this article (https://doi.org/10.1007/s12286-02100504-6) contains supplementary material, which is available to authorized users.

Acknowledgements I would like to thank very much the participants of the workshop on "Die Rolle politischer Parteien in der Umweltpolitik (The Role of Political Parties in Environmental Policy)" organized by Christiane Hubo, Simon Fink and Annette Töller, Göttingen October 7-8, 2020 for discussion of the paper. Thanks are also due to the extremely useful comments of three reviewers. During the revision of the manuscript, my team in Greifswald, as well as the participants of the weekly chair colloquium, assisted me with further comments. Namely, I would like to thank Lisa Klagges, Sophie Suda, Erik Baltz, and Maximillian Andorff-Woller.

Funding Open Access funding enabled and organized by Projekt DEAL.

Open Access This article is licensed under a Creative Commons Attribution 4.0 International License, which permits use, sharing, adaptation, distribution and reproduction in any medium or format, as long as you give appropriate credit to the original author(s) and the source, provide a link to the Creative Commons licence, and indicate if changes were made. The images or other third party material in this article are included in the article's Creative Commons licence, unless indicated otherwise in a credit line to the material. If material is not included in the article's Creative Commons licence and your intended use is not permitted by statutory regulation or exceeds the permitted use, you will need to obtain permission directly from the copyright holder. To view a copy of this licence, visit http://creativecommons.org/licenses/by/4. $0 \%$.

Conflict of interest D. Jahn declares that he has no competing interests.

\section{References}

Abou-Chadi, Tarik. 2014. Niche party success and mainstream party policy shifts—how green and radical right parties differ in their impact. British Journal of Political Science 46:417-436.

Anderson, Liam. 2001. The implications of institutional design for macroeconomic performance. Reassessing the claims of consensus democracy. Comparative Political Studies 34(4):429-452.

Armingeon, Klaus, Virginia Wenger, Fiona Wiedemeier, Christian Isler, Laura Knöpfel, David Weisstanner, and Sarah Engler. 2020. Comparative political data set 1960-2018. Zurich: Institute of Political Science, University of Zurich.

Beck, Nathaniel, and Jonathan Katz. 1995. What to do (and not to do) with time-series cross-section data. American Political Science Review 89(3):634-647.

Beramendi, Pablo, Silja Häusermann, Herbert Kitschelt, and Hanspeter Kriesi (eds.). 2015. The politics of advanced capitalism. New York: Cambridge University Press.

Bernauer, Thomas. 2013. Climate change politics. Annual Review of Political Science 16(1):421-448.

von Beyme, Klaus. 1985. Political parties in western democracies. Aldershot: Gower.

Bobbio, Norberto. 1996. Left and right. The significance of a political distinction. Cambridge: Polity Press.

Brown, Mark B. 2014. Climate science, populism and the democracy of rejection. In Culture, politics and climate change. How information shapes our common future, ed. Deserai A. Crow, Maxwell T. Boykoff, 129-145. London: Routledge.

Cameron, David R. 1978. The expansion of the public economy: a comparative analysis. American Political Science Review 72(4):1243-1261.

Carter, Neil. 2013. Greening the mainstream: party politics and the environment. Environmental Politics 22(1):73-94.

Cetkovic, Stefan, and Christian Hagemann. 2020. Changing climate for populists? Examining the influence of radical-right political parties on low-carbon energy transitions in Western Europe. Energy Research \& Social Science https://doi.org/10.1016/j.erss.2020.101571. 
Chang, Chun-Ping, Jun Wen, Dong Minyi, and Yu Hao. 2018. Does government ideology affect environmental pollutions? New evidence from instrumental variable quantile regression estimations. Energy Policy 113:386-400.

Cranmer, Skyler J., Douglas R. Rice, and Randolph M. Siverson. 2017. What to do about atheoretic lags. Political Science Research and Methods 5(4):641-665.

Crepaz, Markus M.L. 1995. Explaining national variations in air pollution levels: political institutions and their impact on environmental policy making. Environmental Politics 4(3):391-414.

Cruz, Cesi, Philip Keefer, and Carlos Scartascini. 2021. DPI2020 database of political institutions: department of research and chief economists. Washington, D.C.: Inter-American Development Bank. https://doi.org/10.18235/0003049.

Dalton, Russell J. 1991. Responsiveness of parties and party systems to the new politics. In Politische Klasse und politische Institutionen, ed. Hans-Dieter Klingemann, 39-56. Wiesbaden: VS.

Dalton, Russell J. 2009. Economics, environmentalism and party alignments: a note on partisan change in advanced industrial democracies. European Journal of Political Research 48(2):161-175.

Dobson, Andrew. 2007. Green political thought. New York: Routledge.

Esping-Andersen, Gøsta. 1990. The three worlds of welfare capitalism. Princeton: Princeton University Press.

Farstad, Fay M. 2018. What explains variation in parties' climate change salience? Party Politics 24(6):698-707

Gingrich, Jane, and Silja Häusermann. 2015. The decline of the working-class vote, the reconfiguration of the welfare support coalition and consequences for the welfare state. Journal of European Social Policy 25(1):50-75.

Häusermann, Silja, Georg Picot, and Dominik Geering. 2013. Review article: rethinking party politics and the welfare state-recent advances in the literature. British Journal of Political Science 43(1):221-240.

Hibbs, Douglas A. 1977. Political parties and macroeconomic policy. American Political Science Review 71(4):1467-1487.

Humphrey, Mathew. 2013. Green ideology. In The oxford handbook of political ideologies, ed. Michael Freeden, Lyman T. Sargent, and Marc Stears, 422-438. Oxford: Oxford University Press.

Indridason, Indridi H., and Shaun Bowler. 2013. Determinants of cabinet size. European Journal of Political Research 53(2):381-403.

Jahn, Detlef. 1993. The rise and decline of new politics and the greens in Sweden and Germany. European Journal of Political Research 24(3):177-194.

Jahn, Detlef. 1998. Environmental performance and policy regimes: explaining variations in 18 OECDcountries. Policy Sciences 31(2):107-131.

Jahn, Detlef. 2000. Die Lernfähigkeit politischer Systeme. Zur Institutionalisierung ökologischer Standpunkte in Schweden und der Bundesrepublik Deutschland. Baden-Baden: Nomos.

Jahn, Detlef. 2016. Changing of the guard: trends in corporatist arrangements in 42 highly industrialized societies from 1960 to 2010. Socio-Economic Review 14(1):47-71.

Jahn, Detlef. 2018. The politics of environmental performance: institutions and preferences in industrialized democracies. Cambridge: Cambridge University Press.

Jahn, Detlef. 2021. Quick and dirty: how populist parties in government affect greenhouse gas emissions in EU member states. Journal of European Public Policy 28(7):980-997.

Jänicke, Martin, and Klaus Jacob (eds.). 2007. Environmental governance in global perspective. New approaches to ecological modernisation, 2nd edn., Berlin: Free University of Berlin.

Janoski, Thomas, and Larry W. Isaac. 1994. Introduction to time-series analysis. In The comparative political economy of the welfare state, ed. Thomas Janoski, Alexander M. Hicks, 31-53. Cambridge: Cambridge University Press.

Jensen, Christian B., and Jae-Jae Spoon. 2011. Testing the 'party matters' thesis: explaining progress towards Kyoto protocol targets. Political Studies 59(1):99-115.

Jun, Uwe, and Benjamin Höhne. 2012. Parteienfamilien: Identitätsbestimmend oder nur noch Etikett? Opladen: Barbara Budrich.

van Kersbergen, Kees. 1995. Social capitalism: a study of christian democracy and the welfare state. London: Routledge.

Kitschelt, Herbert. 1988. Left-libertarian parties: explaining innovation in competitive party systems. World Politics 40(2):194-234.

Kitschelt, Herbert. 1994. The transformation of European social democracy. Cambridge: Cambridge University Press. 
Klagges, Lisa. 2019. Ökologische Performanz von Mehrheits- und Konsensdemokratien. Eine empirische Analyse der OECD-Länder 2000 bis 2015. Mainz: Johannes Gutenberg-Universität.

Knill, Christoph, Marc Debus, and Stephan Heichel. 2010. Do parties matter in internationalised policy areas? The impact of political parties on environmental policy outputs in 18 OECD countries, 1970-2000. European Journal of Political Research 49(3):301-336.

Lijphart, Arend. 2012. Patterns of democracy. Government forms and performance in thirty-six countries. New Haven: Yale University Press.

Lim, Sijeong, and Andreas Duit. 2018. Partisan politics, welfare states, and environmental policy outputs in the OECD countries, 1975-2005. Regulation \& Governance 12:220-237.

Lockwood, Matthew. 2018. Right-wing populism and the climate change agenda: exploring the linkages. Environmental Politics 27(4):712-732.

Manow, Philip, Bruno Palier, and Hanna Schwander (eds.). 2018. Welfare democracies and party politics. Explaining electoral dynamics in times of changing welfare capitalism. Oxford: Oxford University Press.

McDonald, Michael D., and Ian Budge. 2005. Elections, parties, democracy. Conferring the median mandate. Oxford: Oxford University Press.

Mol, Arthur P.J., David A. Sonnenfeld, and Gert Spaargaren (eds.). 2009. The ecological modernization reader. Environmental reform in theory and practice. London: Routledge.

Müller-Rommel, Ferdinand. 1989. New politics in western europe: the rise and success of green parties and alternative lists. Boulder: Westview.

Mummolo, Jonathan, and Erik Peterson. 2018. Improving the interpretation of fixed effects regression results. Political Science Research and Methods 6(4):829-835.

Neumayer, Eric. 2003. Are left-wing party strength and corporatism good for the environment? Evidence from panel analysis of air pollution in OECD countries. Ecological Economics 45(2):203-220.

Neumayer, Eric, and Thomas Plümper. 2017. Robustness tests for quantitative research. Cambridge: Cambridge University Press.

Panebianco, Angelo. 1988. Political parties: organization and power. Cambridge: Cambridge University Press.

Plümper, Thomas, and Vera E. Troeger. 2019. Not so harmless after all: the fixed-effects model. Political Analysis 27(1):21-45.

Plümper, Thomas, Vera E. Troeger, and Philip Manow. 2005. Panel data analysis in comparative politics: linking method to theory. European Journal of Political Research 44(2):327-354.

Potrafke, Niklas. 2017. Partisan politics. The empirical evidence from OECD panel studies. Journal of Comparative Economics 45(4):712-750.

Roller, Edeltraud. 2005. The performance of democracies. Political institutions and public policies. Oxford: Oxford University Press.

Schmidt, Manfred G. 1982. The role of the parties in shaping macroeconomic policy. In The impact of parties: politics and policies in democratic capitalist states, ed. Francis G. Castles, 97-176. London: SAGE.

Schmidt, Manfred G. 1996. When parties matter: a review of the possibilities and limits of partisan influence on public policy. European Journal of Political Research 30(2):155-183.

Schmidt, Manfred G., Reimut Zohlnhöfer, Falk Bartscherer, and Caroline Trocka. 2020. The partisan composition of governments database (PACOGOV), version 1.0. Heidelberg: University of Heidelberg.

Scruggs, Lyle. 1999. Institutions and environmental performance in seventeen western democracies. British Journal of Political Science 29(1):1-31.

Scruggs, Lyle. 2001. Is there really a link between neo-corporatism and environmental performance? Updated evidence and new data for the 1980s and 1990s. British Journal of Political Science 31(4):686-692.

Scruggs, Lyle. 2003. Sustaining abundance. Environmental performance in industrial democracies. Cambridge: Cambridge University Press.

Smith, Gordon. 1988. Between left and right: the ambivalence of European liberalism. In Liberal parties in western europe, ed. Emil J. Kirchner, 16-28. Cambridge: Cambridge University Press.

Spoon, Jae-Jae, Sara B. Hobolt, and Catherine de Vries. 2014. Going green: explaining issue competition on the environment. European Journal of Political Research 53(2):363-380.

Stephens, John D. 1979. The transition from capitalism to socialism. Urbana: University of Illinois Press.

Swank, Duane. 2018. Comparative political parties dataset: electoral, legislative, and government strength of political parties by ideological group in 21 capitalist democracies, 1950-2015. Milwaukee: Department of Political Science, Marquette University.

Tufte, Edward R. 1978. Political control of the economy. Princeton: Princeton University Press. 
Ward, Hugh, and Xun Cao. 2012. Domestic and international influences on green taxation. Comparative Political Studies 45(9):1075-1103.

Ware, Alan. 1996. Political parties and party systems. Oxford: Oxford University Press.

Wooldridge, Jeffrey M. 2000. Introductory econometrics: a modern approach. Cincinnati: South-Western College.

Young, Stephen C. (ed.). 2000. The emergence of ecological modernisation: integrating the environment and the economy? London: Routledge.

Zohlnhöfer, Reimut. 2020. The analysis of partisan differences in advanced democracies: the "independent variable problem” reconsidered. Heidelberg: University of Heidelberg. Unpublishes manuscript.

Zohlnhöfer, Reimut, Fabian Engler, and Kathrin Dümig. 2017. The retreat of the interventionist state in advanced democracies. British Journal of Political Science 48(2):535-562. 